\title{
IMPLEMENTASI METODE MODIFIED CHAIN CODE UNTUK PENGENALAN RAMBU LALU LINTAS
}

\author{
Ryan Agustian ${ }^{1}$ \\ ry.agustian@ti.ukdw.ac.id
}

\author{
Nugroho Agus H. ${ }^{2}$ \\ nugroho@ti.ukdw.ac.id
}

\author{
Junius $\mathrm{Karel}^{3}$ \\ karel@ti.ukdw.ac.id
}

\begin{abstract}
Traffic sign is needed to give information to users so they can be aware in roads. There are many types of traffic signs and each has many forms and different from each other so users sometimes have difficuty in recognizing traffic signs. In this research, the signs used are signs based on Peraturan Menteri Perhubungan Republik Indonesia Nomor PM 13 Tahun 2014. Modified Chain Code method was implemented for feature extraction process and Euclidean Distance method is used to calculating the similarity. Testing is done with 5 types of tests i.e. resize image, objects truncated, added a few objects to image, added many objects to image and noise spots. The test results showed the accuracy of the image of traffic signs to be recognized is $92.5 \%$.
\end{abstract}

Keywords : Traffic Sign, Chain Code, Euclidean Distance

\section{PENDAHULUAN}

Rambu lalu lintas memiliki peran penting dalam mengatur kelancaran lalu lintas para pengguna jalan baik kendaraan maupun pejalan kaki. Rambu lalu lintas digunakan sebagai media untuk menyampaikan informasi berkaitan dengan jalan raya kepada para pengguna jalan. Namun, selama ini masih sering terjadi kecelakaan dikarenakan kesalahan manusia (human error). Hal sepele yang menjadi penyebab kecelakaan tersebut seperti tidak memperhatikan dan tidak paham arti dari rambu lalu lintas. Permasalahan yang dihadapi adalah bagaimana mendeteksi dan mengenali rambu lalu lintas dengan banyak jenis dan bentuknya yang berbeda satu sama lain. Tujuan penelitian ini adalah untuk mendeteksi dan mengenali rambu lalu lintas dengan menggunakan metode Modified Chain Code.

Penelitian tentang pengenalan rambu lalu lintas telah banyak dilakukan misalnya pengenalan rambu lalu lintas sederhana dengan metode Template Matching (Mulyadi, 2002) dan penggunaan Shape Number pada Chain Code (Imelda \& Hartati, 2013). Beberapa kelemahan pada penelitian sebelumnya seperti resolusi gambar, banyaknya noise, gambar terputus dan garis melintang akan sangat memengaruhi persentase rambu lalu lintas dikenali. Penelitian dengan menggunakan metode Modified Chain Code untuk pengenalan rambu lalu lintas belum pernah dilakukan sebelumnya.

Pada penelitian ini akan dibuat sebuah aplikasi pengenalan rambu lalu lintas. Aplikasi yang dibangun akan mengimplementasikan salah satu metode pengenalan pola yaitu Chain Code. Kemudian, untuk menghitung similaritas data citra yang diuji dengan data citra yang ada di dalam basis-data digunakan metode SNH (Modified Chain Code) dan Euclidean Distance. Dengan adanya aplikasi ini diharapkan dapat membantu masyarakat luas khususnya pengguna jalan raya dalam mengenali rambu lalu lintas sehingga bisa mengurangi angka kecelakaan akibat kelalaian tidak memperhatikan rambu lalu lintas.

\footnotetext{
${ }^{1}$ Program Studi Teknik Informatika, Fakultas Teknologi Informasi,Universitas Kristen Duta Wacana ${ }^{2}$ Program Studi Teknik Informatika, Fakultas Teknologi Informasi,Universitas Kristen Duta Wacana ${ }^{3}$ Program Studi Teknik Informatika, Fakultas Teknologi Informasi,Universitas Kristen Duta Wacana
} 
Data yang digunakan dalam penelitian ini adalah data citra rambu lalu lintas sesuai dengan Peraturan Menteri Perhubungan Republik Indonesia Nomor PM 13 Tahun 2014. Terdapat 4 jenis rambu yaitu: Rambu Peringatan, Rambu Larangan, Rambu Perintah dan Rambu Petunjuk. Jumlah data yang digunakan untuk basis-data adalah 135 citra terbagi menjadi Rambu Peringatan sebanyak 59 citra, Rambu Larangan sebanyak 25 citra, Rambu Perintah sebanyak 21 citra, dan Rambu Petunjuk sebanyak 30 citra. Kemudian, data citra rambu lalu lintas yang digunakan untuk pengujian aplikasi pengenalan citra rambu lalu lintas kurang lebih sebanyak 200 citra. 40 citra rambu lalu lintas untuk setiap jenis pengujian. Masing-masing jenis citra rambu lalu lintas sebanyak 10 citra untuk masing-masing pengujian.

\section{METODOLOGI PENELITIAN}

Aplikasi pengenalan citra rambu lalu lintas ini dibangun dengan 2 proses utama yaitu proses penyimpanan dan proses pengujian. Proses penyimpanan dilakukan untuk menyimpan hasil normalisasi Chain Code citra ke dalam basis-data, sedangkan proses pengujian dilakukan untuk menghitung similaritas hasil normalisasi Chain Code citra datauji dengan citra yang ada di dalam basis-data.

\subsection{Proses Penyimpanan}

Pada prose penyimpanan, citra yang akan digunakan sebagai basis-data terlebih dahulu diekstraksi fiturnya dimulai dari resize citra menjadi ukuran 256 x 256 piksel, melakukan segmentasi warna untuk menentukan citra rambu lalu lintas masuk dalam basis-data rambu lalu lintas jenis Rambu Peringatan, Rambu Larangan, Rambu Perintah, atau Rambu Petunjuk. Kemudian, citra tersebut diubah menjadi citra keabuan (grayscale) lalu diubah menjadi citra biner. Proses selanjutnya adalah labeling, untuk memberi label pada setiap objek yang ada pada citra untuk selanjutnya dilakukan proses Chain Code. Setelah mendapatkan nilai Chain Code kemudian lakukan normalisasi nilai histogram dari tiap angka 0 hingga 7 (8-connectivity) lalu urutkan secara ascending. Hasil pengurutan nilai histogram secara ascending inilah yang akan disimpan di basis-data untuk selanjutnya diuji similaritasnya dengan citra datauji.

\subsection{Proses Ekstraksi Fitur}

\section{a. Citra Grayscale}

Citra grayscale adalah suatu citra dimana nilai dari setiap piksel merupakan sample tunggal. Citra yang ditampilkan dari citra jenis ini terdiri atas warna abu - abu, bervariasi pada warna hitam pada bagian yang intensitas terlemah dan warna putih pada intensitas terkuat. Citra grayscale disimpan dalam format 8 bit untuk setiap sample piksel, yang memungkinkan sebanyak 256 intensitas. Format ini sangat membantu dalam pemrograman karena manipulasi bit yang tidak terlalu banyak (Fatta, 2007). Hasil pengubahan citra menjadi citra grayscale ini akan digunakan sebagai input untuk proses selanjutnya yaitu citra biner.

Nilai grayscale dapat diperoleh dengan menggunakan rumus :

$$
\text { grayscale }=0.3 * \mathrm{R}+0.59 * \mathrm{G}+0.11 * \mathrm{~B}
$$

grayscale adalah nilai grayscale dari citra.

$\mathrm{R}$ adalah nilai warna merah (Red) dari citra.

$\mathrm{G}$ adalah nilai warna hijau (Green) dari citra.

$\mathrm{B}$ adalah nilai warna biru (Blue) dari citra.

\section{b. Chain Code}

Chain Code merupakan metode yang digunakan untuk merepresentasikan batas objek yang dinyatakan dengan rantai arah (Gonzales \& Woods, 2002). Sebelum dilakukan pengkodean menggunakan Chain Code, terlebih dahulu batas objek pada citra harus divisualisasikan kedalam Rectangular Cell. Rectangular Cell merupakan sel-sel berbentuk segiempat, dimana kontur atau batas objek dapat digambarkan pada sisi-sisi dari sel.

Chain Code memiliki beberapa keunggulan antara lain: 
1. Chain Code adalah representasi padat suatu objek biner.

2. Lebih mudah untuk membandingkan objek menggunakan metode Chain Code karena merupakan representasi terjemahan invarian suatu objek biner.

3. Chain Code dapat digunakan untuk menghitung suatu fitur bentuk karena merupakan representasi lengkap dari suatu objek atau kurva.

4. Chain Code juga menyediakan kompresi loseless dan mempertahaknlan semua topologi dan morfologi dari suatu informasi yang akan berguna dalam analisi pola garis dalam hal kecepatan dan efektivitas (Boodoo-Jahangeer, 2013)

Terdapat dua arah dalam Chain Code yaitu arah dalam ketetanggan empat yang artinya memiliki empat arah seperti mata angin yaitu Utara, Timur, Selatan dan Barat. Kemudian, arah dalam ketetanggaan delapan yang artinya memiliki delapan arah seperti pada Gambar 1.
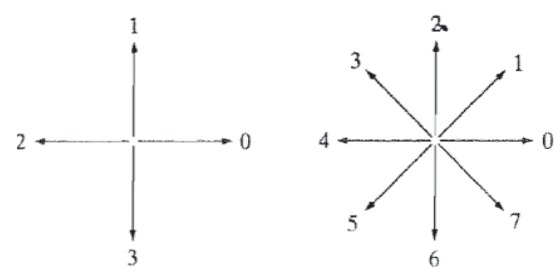

Gambar 1. Arah dalam Ketetanggaan Empat dan Delapan Chain Code

\{ Sumber: http://www.prenhall.com/gonzaleswoods \}

\section{c. Modified Chain Code}

Metode Chain Code tradisional memiliki masalah jika pada gambar terdapat sedikit noise seperti perbedaan ukuran, rotasi atau adanya objek tambahan (Ahmad, Park, Chang, YoungSuk, \& Choi, 2003). Noise ini akan memberikan perubahan kecil terhadap kode rantai, sehingga menyebabkan adanya ketidakcocokan pada hasil akhirnya nanti. Oleh karena itu, metode baru berdasarkan histogram dari Chain Code digunakan untuk mencocokkan kode yang dihasilkan dari Chain Code tradisional.

Diasumsikan terdapat 2 buah gambar dengan 2 buah nilai Chain Code:

Keterangan :

$$
\begin{aligned}
& c c 1=\text { chaincodes }(G 1) \\
& c c 2=\text { chaincodes }(G 2)
\end{aligned}
$$$$
\text { NH1 = histogram }(c c 1) / \text { length }(c c 1)
$$$$
\text { NH2 = histogram }(c c 2) / \text { length }(c c 2)
$$

$G$ adalah gambar

cc adalah Chain Code yang didapatkan dari masing-masing gambar

length(cc) adalah panjang Chain Code

histogram(cc) adalah jumlah kemunculan dari Chain Code (menggunakan ketetanggaan delapan sehingga dari 0 - 7)

$\mathrm{NH}$ adalah normalisasi dari histogram Chain Code

Setelah didapatkan nilai normalisasi Chain Code kemudian dilanjutkan dengan mengurutkan nilai normalisasi tersebut secara ascending (dari nilai terkecil hingga nilai terbesar) untuk selanjutnya dihitung similaritas-nya dengan menggunakan metode Euclidean Distance.

$$
\text { SNH1 }=\operatorname{sort}(\mathrm{NH} 1)
$$$$
\text { SNH2 }=\operatorname{sort}(N H 1)
$$

Keterangan :

$\mathrm{SNH}$ adalah hasil pengurutan dari normalisasi tiap gambar yang telah disusun secara ascending. 


\subsection{Proses Pengujian}

\section{a. Pengambilan Sampel Citra Rambu Lalu Lintas}

Pada saat dilakukan proses penginputan, data citra dapat berbeda-beda ukurannya Oleh karena itu data perlu diubah ukurannya sehingga proses perhitungan Chain Code dapat dikerjakan dengan lebih cepat juga memperkecil kemugnkinan inforamsi yang tidak tepat. Ukuran gambar dapat diubah menjadi 256 x 256 piksel atau 512 x 512 piksel. Dengan ukuran ini gambar masih dapat dikenali dengan baik.

\section{b. Euclidean Distance}

Euclidean Distance merupakan salah satu metode yang paling cepat, sederhana dan paling sering digunakan untuk menentukan kesamaan jarak antara dua buah gambar ataupun vektor (Ahmad, Park, Chang, Young-Suk, \& Choi, 2003).

$$
D_{E}=\sqrt{\sum_{k=0}^{N-1}(Q[k]-C[k])^{2}},
$$

Keterangan :

$k$ adalah nilai Chain Code terkecil yaitu 0

$Q$ adalah nilai $S N H$ dari gambar datauji

$C$ adalah nilai $S N H$ dari gambar yang ada di basis-data

$N$ adalah nilai Chain Code terbesar yaitu 7

\section{HASIL DAN PEMBAHASAN}

Data citra rambu lalu lintas yang digunakan untuk pengujian aplikasi pengenalan citra rambu lalu lintas kurang lebih sebanyak 200 citra. 40 citra rambu lalu lintas untuk setiap jenis pengujian. Masing-masing jenis citra rambu lalu lintas sebanyak 10 citra untuk masing-masing pengujian, dengan warna latar belakang citra berwarna putih dan diambil menggunakan kamera. Langkah pertama yang dilakukan adalah mengubah ukuran citra menjadi 256 x 256 piksel atau 512 x 512 piksel.

Proses selanjutnya yang akan dilakukan adalah pemilihan jenis citra berdasarkan segmentasi warna dasarnya. Jenis rambu akan dipisah menjadi 4 yaitu Rambu Peringatan dengan warna dasar kuning, Rambu Larangan dengan warna dasar merah, Rambu Perintah dengan warna dasar biru dengan intensitas warna hitam dibawah $20 \%$ dari warna biru, dan Rambu Petunjuk dengan warna dasar biru dengan intensitas warna hitam diatas $20 \%$ dari warna biru.

Kemudian, citra diubah menjadi grayscale, untuk selanjutnya diubah menjadi citra biner. Proses berikutnya adalah labeling untuk mengetahui banyaknya objek dalam satu citra datauji, dan mengimplementasikan metode Chain Code untuk menghitung nilai Chain Code dari tiap objek dalam citra. Selanjutnya, menggunakan metode Modified Chain Code dan menghitung nilai normalisasi histogram Chain Code untuk selanjutnya nilai dari datauji dihitung similaritasnya dengan data yang ada pada basis-data menggunakan metode Euclidean Distance.

Gambar 2. A merupakan contoh citra datauji yang ditambah sedikit objek, Gambar 2. B merupakan contoh citra datauji yang ditambah banyak objek. Citra datauji ditambah tidak selalu sama ukuran, bentuk objek dan letak objeknya. Ukuran yang digunakan bisa berbeda-beda begitu pula dengan bentuk dan letak objek yang ditambah. Gambar 2. C merupakan contoh citra datauji yang diberi noise berupa bintik-bintik kecil secara merata pada citra datauji. 


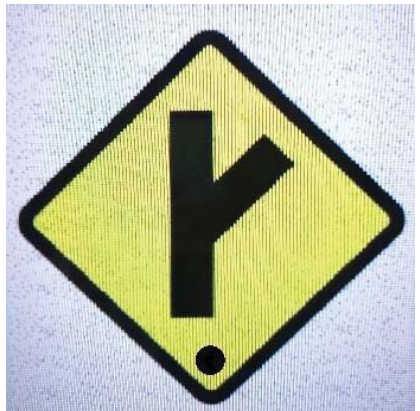

A

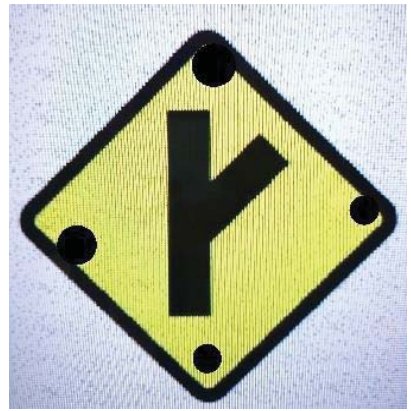

B

Gambar 2. Gambar A

citra datauji dengan

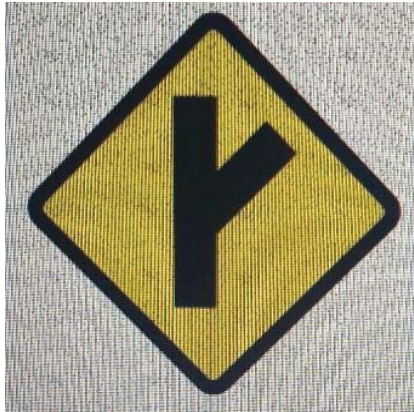

C citra datauji dengan banyak objek, Gambar $\mathrm{C}$ citra datauji dengan bintik berikut:

Berdasarkan pengujian yang dilakukan oleh penulis, maka didapatkan hasil sebagai

\subsection{Pengujian Citra Rambu Lalu Lintas Jenis Rambu Larangan}

Tabel 1. menunjukkan rata-rata persentase citra rambu lalu lintas jenis Rambu Larangan dapat dikenali adalah sebesar $84 \%$. Dengan masing-masing persentase pengujian sebesar $100 \%$ pada pengujian dengan mengubah ukuran (resize) citra,, $80 \%$ untuk pengujian dengan sedikit bagian rambu lalu lintas terpotong dan ditambah sedikit objek, persentase pengujian dengan memberikan banyak objek tambahan pada citra datauji sebesar $70 \%$, dan $90 \%$ untuk pengujian dengan memberikan bintik kepada citra datauji.

Tabel 1.

Hasil Pengujian Citra Rambu Lalu Lintas Jenis Rambu Larangan

\begin{tabular}{|c|c|c|c|c|c|c|c|c|c|c|c|}
\hline \multirow{4}{*}{ Datauji } & \multirow{4}{*}{ Nama Rambu } & \multicolumn{10}{|c|}{ Jenis Pengujian } \\
\hline & & \multirow{2}{*}{\multicolumn{2}{|c|}{$\begin{array}{c}\begin{array}{c}\text { Resize } \\
\text { piskel }\end{array} \\
\text { Dikenali }\end{array}$}} & \multirow{2}{*}{\multicolumn{2}{|c|}{$\begin{array}{c}\begin{array}{c}\text { Objek } \\
\text { Terpotong }\end{array} \\
\text { Dikenali }\end{array}$}} & \multirow{2}{*}{\multicolumn{2}{|c|}{$\begin{array}{c}\begin{array}{c}\text { Sedikit } \\
\text { Objek }\end{array} \\
\text { Dikenali }\end{array}$}} & \multirow{2}{*}{\multicolumn{2}{|c|}{$\begin{array}{c}\begin{array}{c}\text { Banyak } \\
\text { Objek }\end{array} \\
\text { Dikenali }\end{array}$}} & \multicolumn{2}{|c|}{ Bintik } \\
\hline & & & & & & & & & & \multicolumn{2}{|c|}{ Dikenali } \\
\hline & & $\mathrm{Y}$ & $\mathrm{T}$ & $\mathrm{Y}$ & $\mathrm{T}$ & $\mathrm{Y}$ & $\mathrm{T}$ & $\mathrm{Y}$ & $\mathrm{T}$ & $\mathrm{Y}$ & $\mathrm{T}$ \\
\hline 1 & $\begin{array}{l}\text { Larangan Masuk Bagi } \\
\text { Kendaraan Bermotor dengan } \\
\text { Kereta Gandeng } \\
\end{array}$ & $\sqrt{ }$ & & $\sqrt{ }$ & & $\sqrt{ }$ & & $\sqrt{ }$ & & $\sqrt{ }$ & \\
\hline 2 & Larangan Belok Kanan & $\sqrt{ }$ & & $\sqrt{ }$ & & $\sqrt{ }$ & & $\sqrt{ }$ & & $\sqrt{ }$ & \\
\hline 3 & Larangan Masuk Bagi Sepeda & $\sqrt{ }$ & & & $\sqrt{ }$ & & $\sqrt{ }$ & & $\sqrt{ }$ & & $\sqrt{ }$ \\
\hline 4 & $\begin{array}{l}\text { Larangan Masuk Bagi } \\
\text { Kendaraan Khusus }\end{array}$ & $\sqrt{ }$ & & & $\sqrt{ }$ & $\sqrt{ }$ & & $\sqrt{ }$ & & $\sqrt{ }$ & \\
\hline 5 & $\begin{array}{l}\text { Larangan Masuk Bagi Pejalan } \\
\text { Kaki }\end{array}$ & $\sqrt{ }$ & & $\sqrt{ }$ & & $\sqrt{ }$ & & $\sqrt{ }$ & & $\sqrt{ }$ & \\
\hline 6 & $\begin{array}{l}\text { Larangan Masuk Bagi } \\
\text { Kendaraan Bermotor dengan JBI } \\
\text { Sama atau Lebih dari } 5 \text { ton }\end{array}$ & $\sqrt{ }$ & & $\sqrt{ }$ & & $\sqrt{ }$ & & & $\sqrt{ }$ & $\sqrt{ }$ & \\
\hline 7 & $\begin{array}{l}\text { Larangan Masuk Bagi Gerobak } \\
\text { Dorong dan Sejenisnya }\end{array}$ & $\sqrt{ }$ & & $\sqrt{ }$ & & $\sqrt{ }$ & & $\sqrt{ }$ & & $\sqrt{ }$ & \\
\hline 8 & $\begin{array}{l}\text { Larangan Masuk Bagi } \\
\text { Kendaraan Bermotor dengan } \\
\text { Kereta Tempel }\end{array}$ & $\sqrt{ }$ & & $\sqrt{ }$ & & $\sqrt{ }$ & & $\sqrt{ }$ & & $\sqrt{ }$ & \\
\hline 9 & $\begin{array}{l}\text { Larangan Masuk Bagi Sepeda } \\
\text { Motor }\end{array}$ & $\sqrt{ }$ & & $\sqrt{ }$ & & & $\sqrt{ }$ & & $\sqrt{ }$ & $\sqrt{ }$ & \\
\hline 10 & $\begin{array}{l}\text { Larangan Masuk Bagi } \\
\text { Kendaraan Bermotor Roda } \\
\text { Tunggal dengan MST Sama atau } \\
\text { Lebih dari } 8 \text { Meter }\end{array}$ & $\sqrt{ }$ & & $\sqrt{ }$ & & $\sqrt{ }$ & & $\sqrt{ }$ & & $\sqrt{ }$ & \\
\hline & Jumlah & 10 & 0 & 8 & 2 & 8 & 2 & 7 & 3 & 9 & 1 \\
\hline & Persentase & \multicolumn{2}{|c|}{$100 \%$} & \multicolumn{2}{|c|}{$80 \%$} & \multicolumn{2}{|c|}{$80 \%$} & \multicolumn{2}{|c|}{$70 \%$} & \multicolumn{2}{|c|}{$90 \%$} \\
\hline & Rata-rata & \multicolumn{10}{|c|}{$84 \%$} \\
\hline
\end{tabular}




\subsection{Pengujian Citra Rambu Lalu Lintas Jenis Rambu Peringatan}

Pada Tabel 2. menunjukkan rata-rata persentase citra rambu lalu lintas jenis Rambu Peringatan dapat dikenali adalah sebesar $88 \%$. Dengan masing-masing persentase pengujian sebesar $100 \%$ pada pengujian dengan mengubah ukuran (resize) citra datauji, 80\% pada pengujian dengan sedikit bagian rambu lalu lintas terpotong, 90\% pada pengujian dengan memberi satu atau dua objek tambahan kepada citra datauji, $90 \%$ pengujian dengan memberikan noise berupa bintik-bintik kecil, dan pada pengujian dengan memberikan banyak objek tambahan pada citra datauji sebesar diperoleh rata-rata persentase sebesar $80 \%$ citra rambu lalu lintas dapat dikenali dengan baik.

Tabel 2 .

Hasil Pengujian Citra Rambu Lalu Lintas Jenis Rambu Peringatan

\begin{tabular}{|c|c|c|c|c|c|c|c|c|c|c|c|}
\hline \multirow{4}{*}{ Datauji } & \multirow{4}{*}{ Nama Rambu } & \multicolumn{10}{|c|}{ Jenis Pengujian } \\
\hline & & \multicolumn{2}{|c|}{$\begin{array}{l}\text { Resize } \\
\text { piskel }\end{array}$} & \multicolumn{2}{|c|}{$\begin{array}{c}\text { Objek } \\
\text { Terpotong }\end{array}$} & \multicolumn{2}{|c|}{$\begin{array}{l}\text { Sedikit } \\
\text { Objek }\end{array}$} & \multicolumn{2}{|c|}{$\begin{array}{c}\text { Banyak } \\
\text { Objek }\end{array}$} & \multicolumn{2}{|c|}{ Bintik } \\
\hline & & \multicolumn{2}{|c|}{ Dikenali } & \multicolumn{2}{|c|}{ Dikenali } & \multicolumn{2}{|c|}{ Dikenali } & \multicolumn{2}{|c|}{ Dikenali } & \multicolumn{2}{|c|}{ Dikenali } \\
\hline & & Y & $\mathrm{T}$ & $\mathrm{Y}$ & $\mathrm{T}$ & Y & $\mathrm{T}$ & Y & $\mathrm{T}$ & Y & $\mathrm{T}$ \\
\hline 1 & Peringatan Jembatan & $\sqrt{ }$ & & $\sqrt{ }$ & & $\sqrt{ }$ & & $\sqrt{ }$ & & $\sqrt{ }$ & \\
\hline 2 & $\begin{array}{l}\text { Peringatan Penambahan Lajur } \\
\text { Kanan }\end{array}$ & $\sqrt{ }$ & & $\sqrt{ }$ & & $\sqrt{ }$ & & $\sqrt{ }$ & & $\sqrt{ }$ & \\
\hline 3 & $\begin{array}{l}\text { Peringatan Pelebaran Badan } \\
\text { Jalan di Kiri }\end{array}$ & $\sqrt{ }$ & & $\sqrt{ }$ & & & $\sqrt{ }$ & & $\sqrt{ }$ & $\sqrt{ }$ & \\
\hline 4 & $\begin{array}{l}\text { Peringatan Simpang Tiga Serong } \\
\text { Kanan }\end{array}$ & $\sqrt{ }$ & & $\sqrt{ }$ & & $\sqrt{ }$ & & $\sqrt{ }$ & & $\sqrt{ }$ & \\
\hline 5 & $\begin{array}{l}\text { Peringatan Penyempitan Badan } \\
\text { Jalan di Kiri Kanan }\end{array}$ & $\sqrt{ }$ & & $\sqrt{ }$ & & $\sqrt{ }$ & & & $\sqrt{ }$ & $\sqrt{ }$ & \\
\hline 6 & $\begin{array}{l}\text { Peringatan Persimpangan Tiga } \\
\text { Berganda Sisi Kanan Lengan } \\
\text { Mayor }\end{array}$ & $\sqrt{ }$ & & & $\sqrt{ }$ & $\sqrt{ }$ & & $\sqrt{ }$ & & $\sqrt{ }$ & \\
\hline 7 & $\begin{array}{l}\text { Peringatan Banyak Lalu Lintas } \\
\text { Pejalan Kaki }\end{array}$ & $\sqrt{ }$ & & $\sqrt{ }$ & & $\sqrt{ }$ & & $\sqrt{ }$ & & $\sqrt{ }$ & \\
\hline 8 & $\begin{array}{l}\text { Peringatan Tikungan Ganda } \\
\text { Tikungan Tajam Kiri }\end{array}$ & $\sqrt{ }$ & & $\sqrt{ }$ & & $\sqrt{ }$ & & $\sqrt{ }$ & & $\sqrt{ }$ & \\
\hline 9 & $\begin{array}{l}\text { Peringatan Pintu Perlintasan } \\
\text { Sebidang Kereta Api }\end{array}$ & $\sqrt{ }$ & & & $\sqrt{ }$ & $\sqrt{ }$ & & $\sqrt{ }$ & & & $\sqrt{ }$ \\
\hline 10 & $\begin{array}{l}\text { Peringatan Tikungan Tajam } \\
\text { Kanan }\end{array}$ & $\sqrt{ }$ & & $\sqrt{ }$ & & $\sqrt{ }$ & & $\sqrt{ }$ & & $\sqrt{ }$ & \\
\hline & Jumlah & 10 & 0 & 8 & 2 & 9 & 1 & 8 & 2 & 9 & 1 \\
\hline & Persentase & \multicolumn{2}{|c|}{$100 \%$} & \multicolumn{2}{|c|}{$80 \%$} & \multicolumn{2}{|c|}{$90 \%$} & \multicolumn{2}{|c|}{$80 \%$} & \multicolumn{2}{|c|}{$90 \%$} \\
\hline & Rata-rata & \multicolumn{10}{|c|}{$88 \%$} \\
\hline
\end{tabular}

\subsection{Pengujian Citra Rambu Lalu Lintas Jenis Rambu Perintah}

Pada Tabel 3 menunjukkan rata-rata persentase citra rambu lalu lintas jenis Rambu Perintah dapat dikenali adalah sebesar 100\%. Dengan kata lain, dari semua jenis pengujian yang telah dilakukan kepada sistem baik pengujian dengan mengubah ukuran (resize) citra, pengujian dengan sedikit objek terpotong, memberi sedikit dan banyak objek ataupun pengujian dengan memberikan bintik, sistem mampu mengenali semua citra dengan baik. 
Tabel 3.

Hasil Pengujian Citra Rambu Lalu Lintas Jenis Rambu Perintah

\begin{tabular}{|c|c|c|c|c|c|c|c|c|c|c|c|}
\hline \multirow{4}{*}{ Datauji } & \multirow{4}{*}{ Nama Rambu } & \multicolumn{10}{|c|}{ Jenis Pengujian } \\
\hline & & \multirow{2}{*}{\multicolumn{2}{|c|}{$\begin{array}{l}\text { Resize } \\
512 \times 512 \\
\text { piskel } \\
\text { Dikenali }\end{array}$}} & \multirow{2}{*}{\multicolumn{2}{|c|}{$\begin{array}{c}\begin{array}{c}\text { Objek } \\
\text { Terpotong }\end{array} \\
\text { Dikenali }\end{array}$}} & \multirow{2}{*}{\multicolumn{2}{|c|}{$\begin{array}{c}\begin{array}{c}\text { Sedikit } \\
\text { Objek }\end{array} \\
\text { Dikenali }\end{array}$}} & \multirow{2}{*}{\multicolumn{2}{|c|}{$\begin{array}{c}\begin{array}{c}\text { Banyak } \\
\text { Objek }\end{array} \\
\text { Dikenali }\end{array}$}} & \multicolumn{2}{|c|}{ Bintik } \\
\hline & & & & & & & & & & \multicolumn{2}{|c|}{ Dikenali } \\
\hline & & $\mathrm{Y}$ & $\mathrm{T}$ & $\mathrm{Y}$ & $\mathrm{T}$ & $\mathrm{Y}$ & $\mathrm{T}$ & $\mathrm{Y}$ & $\mathrm{T}$ & $\mathrm{Y}$ & $\mathrm{T}$ \\
\hline 1 & $\begin{array}{l}\text { Kecepatan Minimum yang } \\
\text { Diperintahkan }\end{array}$ & $\sqrt{ }$ & & $\sqrt{ }$ & & $\sqrt{ }$ & & $\sqrt{ }$ & & $\sqrt{ }$ & \\
\hline 2 & Perintah Belok Ke Arah Kanan & $\sqrt{ }$ & & $\sqrt{ }$ & & $\sqrt{ }$ & & $\sqrt{ }$ & & $\sqrt{ }$ & \\
\hline 3 & Perintah Berjalan Lurus & $\sqrt{ }$ & & $\sqrt{ }$ & & $\sqrt{ }$ & & $\sqrt{ }$ & & $\sqrt{ }$ & \\
\hline 4 & $\begin{array}{l}\text { Perintah Memasuki Jalur atau } \\
\text { Lajur yang Ditunjuk II }\end{array}$ & $\sqrt{ }$ & & $\sqrt{ }$ & & $\sqrt{ }$ & & $\sqrt{ }$ & & $\sqrt{ }$ & \\
\hline 5 & $\begin{array}{l}\text { Perintah Memilih Lurus atau } \\
\text { Belok Kiri }\end{array}$ & $\sqrt{ }$ & & $\sqrt{ }$ & & $\sqrt{ }$ & & $\sqrt{ }$ & & $\sqrt{ }$ & \\
\hline 6 & $\begin{array}{l}\text { Perintah Mengikuti Ke Arah } \\
\text { Kiri }\end{array}$ & $\sqrt{ }$ & & $\sqrt{ }$ & & $\sqrt{ }$ & & $\sqrt{ }$ & & $\sqrt{ }$ & \\
\hline 7 & $\begin{array}{l}\text { Perintah Menggunakan Jalur } \\
\text { atau Lajur Lalu Lintas Khusus } \\
\text { Delman }\end{array}$ & $\sqrt{ }$ & & $\sqrt{ }$ & & $\sqrt{ }$ & & $\sqrt{ }$ & & $\sqrt{ }$ & \\
\hline 8 & $\begin{array}{l}\text { Perintah Menggunakan Jalur } \\
\text { atau Lajur Lalu Lintas Khusus } \\
\text { Sepeda }\end{array}$ & $\sqrt{ }$ & & $\sqrt{ }$ & & $\sqrt{ }$ & & $\sqrt{ }$ & & $\sqrt{ }$ & \\
\hline 9 & $\begin{array}{l}\text { Perintah Mengikuti Arah yang } \\
\text { Ditunjukkan saat Memasuki } \\
\text { Bundaran }\end{array}$ & $\sqrt{ }$ & & $\sqrt{ }$ & & $\sqrt{ }$ & & $\sqrt{ }$ & & $\sqrt{ }$ & \\
\hline 10 & $\begin{array}{l}\text { Perintah Pilihan Memasuki } \\
\text { Salah Satu Jalur atau Lajur } \\
\text { yang Ditunjuk }\end{array}$ & $\sqrt{ }$ & & $\sqrt{ }$ & & $\sqrt{ }$ & & $\sqrt{ }$ & & $\sqrt{ }$ & \\
\hline & Jumlah & 10 & 0 & 10 & 0 & 10 & 0 & 10 & 0 & 10 & 0 \\
\hline & Persentase & \multicolumn{2}{|c|}{$100 \%$} & \multicolumn{2}{|c|}{$100 \%$} & \multicolumn{2}{|c|}{$100 \%$} & \multicolumn{2}{|c|}{$100 \%$} & \multicolumn{2}{|c|}{$100 \%$} \\
\hline & Rata-rata & \multicolumn{10}{|c|}{$100 \%$} \\
\hline
\end{tabular}

\subsection{Pengujian Citra Rambu Lalu Lintas Jenis Rambu Petunjuk}

Pada Tabel 4 menunjukkan rata-rata persentase citra rambu lalu lintas jenis Rambu Perintah dapat dikenali adalah sebesar 98\%. Diperoleh persentase sebesar $100 \%$ untuk pengujian dengan mengubah ukuran (resize) citra, pengujian dengan sedikit objek terpotong, memberi sedikit objek dan pengujian dengan memberikan bintik, sistem mampu mengenali semua citra dengan baik. Namun, pada pengujian dengan memberikan banyak objek pada datauji diperoleh persentase sebesar $90 \%$, karena terdapat 1 citra yang tidak berhasil dikenali dengan baik.

Tabel 4.

Hasil Pengujian Citra Rambu Lalu Lintas Jenis Rambu Petunjuk

\begin{tabular}{|c|c|c|c|c|c|c|c|c|c|c|c|}
\hline \multirow{4}{*}{ Datauji } & \multirow{4}{*}{ Nama Rambu } & \multicolumn{10}{|c|}{ Jenis Pengujian } \\
\hline & & \multirow{2}{*}{\multicolumn{2}{|c|}{$\begin{array}{c}\text { Resize } \\
512 \times 512 \\
\text { piskel } \\
\text { Dikenali }\end{array}$}} & \multirow{2}{*}{\multicolumn{2}{|c|}{$\begin{array}{c}\begin{array}{c}\text { Objek } \\
\text { Terpotong }\end{array} \\
\text { Dikenali }\end{array}$}} & \multirow{2}{*}{\multicolumn{2}{|c|}{$\begin{array}{c}\begin{array}{c}\text { Sedikit } \\
\text { Objek }\end{array} \\
\text { Dikenali }\end{array}$}} & \multicolumn{2}{|c|}{$\begin{array}{c}\text { Banyak } \\
\text { Objek }\end{array}$} & \multicolumn{2}{|c|}{ Bintik } \\
\hline & & & & & & & & & & & \\
\hline & & $\mathrm{Y}$ & $\mathrm{T}$ & $\mathrm{Y}$ & $\mathrm{T}$ & $\mathrm{Y}$ & $\mathrm{T}$ & $\mathrm{Y}$ & $\mathrm{T}$ & $\mathrm{Y}$ & $\mathrm{T}$ \\
\hline 1 & Petunjuk Lokasi Bandar Udara & $\sqrt{ }$ & & $\sqrt{ }$ & & $\sqrt{ }$ & & $\sqrt{ }$ & & $\sqrt{ }$ & \\
\hline 2 & $\begin{array}{l}\text { Petunjuk Lokasi Bangunan } \\
\text { Gereja }\end{array}$ & $\sqrt{ }$ & & $\sqrt{ }$ & & $\sqrt{ }$ & & $\sqrt{ }$ & & $\sqrt{ }$ & \\
\hline
\end{tabular}




\begin{tabular}{|c|c|c|c|c|c|c|c|c|c|c|c|}
\hline \multirow{4}{*}{ Datauji } & \multirow{4}{*}{ Nama Rambu } & \multicolumn{10}{|c|}{ Jenis Pengujian } \\
\hline & & \multirow{2}{*}{\multicolumn{2}{|c|}{$\begin{array}{c}\text { Resize } \\
512 \times 512 \\
\text { piskel } \\
\text { Dikenali }\end{array}$}} & \multirow{2}{*}{\multicolumn{2}{|c|}{$\begin{array}{c}\begin{array}{c}\text { Objek } \\
\text { Terpotong }\end{array} \\
\text { Dikenali }\end{array}$}} & \multirow{2}{*}{\multicolumn{2}{|c|}{$\begin{array}{c}\begin{array}{c}\text { Sedikit } \\
\text { Objek }\end{array} \\
\text { Dikenali }\end{array}$}} & \multicolumn{2}{|c|}{$\begin{array}{l}\text { Banyak } \\
\text { Objek }\end{array}$} & \multicolumn{2}{|c|}{ Bintik } \\
\hline & & & & & & & & \multicolumn{2}{|c|}{ Dikenali } & \multicolumn{2}{|c|}{ Dikenali } \\
\hline & & $\mathrm{Y}$ & $\mathrm{T}$ & $\mathrm{Y}$ & $\mathrm{T}$ & $\mathrm{Y}$ & $\mathrm{T}$ & $\mathrm{Y}$ & $\mathrm{T}$ & $\mathrm{Y}$ & $\mathrm{T}$ \\
\hline 3 & Petunjuk Lokasi Bangunan Pura & $\sqrt{ }$ & & $\sqrt{ }$ & & $\sqrt{ }$ & & & $\sqrt{ }$ & $\sqrt{ }$ & \\
\hline 4 & $\begin{array}{l}\text { Petunjuk Lokasi Pemberhentian } \\
\text { Angkutan Umum }\end{array}$ & $\sqrt{ }$ & & $\sqrt{ }$ & & $\sqrt{ }$ & & $\sqrt{ }$ & & $\sqrt{ }$ & \\
\hline 5 & Petunjuk Lokasi Perpustakaan & $\sqrt{ }$ & & $\sqrt{ }$ & & $\sqrt{ }$ & & $\sqrt{ }$ & & $\sqrt{ }$ & \\
\hline 6 & Petunjuk Lokasi Rumah Makan & $\sqrt{ }$ & & $\sqrt{ }$ & & $\sqrt{ }$ & & $\sqrt{ }$ & & $\sqrt{ }$ & \\
\hline 7 & $\begin{array}{l}\text { Petunjuk Lokasi Rute Lintas } \\
\text { Alam }\end{array}$ & $\sqrt{ }$ & & $\sqrt{ }$ & & $\sqrt{ }$ & & $\sqrt{ }$ & & $\sqrt{ }$ & \\
\hline 8 & Petunjuk Lokasi SPBU & $\sqrt{ }$ & & $\sqrt{ }$ & & $\sqrt{ }$ & & $\sqrt{ }$ & & $\sqrt{ }$ & \\
\hline 9 & $\begin{array}{l}\text { Petunjuk Lokasi Tempat Kemah } \\
\text { Pengungsian }\end{array}$ & $\sqrt{ }$ & & $\sqrt{ }$ & & $\sqrt{ }$ & & $\sqrt{ }$ & & $\sqrt{ }$ & \\
\hline 10 & $\begin{array}{l}\text { Petunjuk Lokasi Perkemahan dan } \\
\text { Perkemahan Menggunakan } \\
\text { Kereta Rumah }\end{array}$ & $\sqrt{ }$ & & $\sqrt{ }$ & & $\sqrt{ }$ & & $\sqrt{ }$ & & $\sqrt{ }$ & \\
\hline & Jumlah & 10 & 0 & 10 & 0 & 10 & 0 & 9 & 1 & 10 & 0 \\
\hline & Persentase & \multicolumn{2}{|c|}{$100 \%$} & \multicolumn{2}{|c|}{$100 \%$} & \multicolumn{2}{|c|}{$100 \%$} & \multicolumn{2}{|c|}{$90 \%$} & \multicolumn{2}{|c|}{$100 \%$} \\
\hline & Rata-rata & \\
\hline
\end{tabular}

Berdasarkan lima jenis pengujian yang telah dilakukan, maka didapat kesimpulan sebagai berikut:

Tabel 5.

Hasil Perhitungan Rata-rata Persentase Hasil Pengujian

\begin{tabular}{|c|c|c|c|c|c|c|}
\hline \multirow[b]{2}{*}{ Jenis Rambu } & \multicolumn{5}{|c|}{ Jenis Pengujian } & \multirow[b]{2}{*}{$\begin{array}{l}\text { Rata- } \\
\text { rata }\end{array}$} \\
\hline & Resize & $\begin{array}{c}\text { Objek } \\
\text { Terpotong }\end{array}$ & $\begin{array}{l}\text { Sedikit } \\
\text { Objek }\end{array}$ & $\begin{array}{c}\text { Banyak } \\
\text { Objek }\end{array}$ & Bintik & \\
\hline Larangan & $100 \%$ & $80 \%$ & $80 \%$ & $70 \%$ & $90 \%$ & $84 \%$ \\
\hline Peringatan & $100 \%$ & $80 \%$ & $90 \%$ & $80 \%$ & $90 \%$ & $88 \%$ \\
\hline Perintah & $100 \%$ & $100 \%$ & $100 \%$ & $100 \%$ & $100 \%$ & $100 \%$ \\
\hline Petunjuk & $100 \%$ & $100 \%$ & $100 \%$ & $90 \%$ & $100 \%$ & $98 \%$ \\
\hline Rata-rata & $100 \%$ & $90 \%$ & $93 \%$ & $85 \%$ & $95 \%$ & $92.5 \%$ \\
\hline
\end{tabular}

Tabel 5 menunjukkan rambu jenis larangan berdasarkan 5 jenis pengujian yang sudah dilakukan memiliki rata-rata persentase citra rambu lalu lintas akan dikenali dengan baik paling kecil, yaitu dengan persentase sebesar $84 \%$. Kemudian, pada pengujian dengan memberikan banyak objek pada citra datauji memiliki rata-rata paling kecil dibandingkan dengan jenis pengujian yang lainnya yaitu dengan persentase rata-rata $85 \%$, sehingga persentase rata-rata rambu lalu lintas akan dikenali adalah sebesar $92.5 \%$.

Penggunaan kamera dan intensitas cahaya bisa menjadi salah satu faktor yang menyebabkan citra rambu lalu lintas tidak dikenali dengan baik. Hal ini bisa saja terjadi, karena hasil jepretan gambar menggunakan kamera biasanya masih memiliki noise sehingga gambar yang diberi noise berupa banyak objek akan ditambah noise dari kamera, sehingga gambar menjadi sulit dikenali. Kemudian, intensitas cahaya juga ikut menjadi salah satu faktor citra datauji tidak dikenali. Hal ini disebabkan jika cahaya terlalu redup, maka warna dasar seperti biru, merah, atau kuning, intensitasnya juga akan turun sehingga akan sulit dikenali. Namun, 
jika intensitas cahaya terlalu banyak/terang, maka warna hitam juga akan sulit dideteksi karena warna hitam akan menjadi sedikit keabu-abuan.

\section{KESIMPULAN}

Tingkat akurasi pengenalan citra rambu lalu lintas dengan mengimplementasikan metode Chain Code sudah terbilang sangat baik dengan persentase rata-rata sebesar 92.5\%, meskipun pada penelitian ini masih banyak datauji citra rambu lalu lintas yang tidak dikenali dengan benar terutama pada pengujian dengan memberikan banyak objek tambahan pada gambar. Penggunaan kamera dan intensitas cahaya bisa menjadi salah satu faktor yang menyebabkan citra rambu lalu lintas tidak dikenali dengan baik.

Untuk pengembangan aplikasi pengenalan citra rambu lalu lintas dapat dilakukan dengan menambah jumlah data citra rambu lalu lintas, tidak hanya di Indonesia tapi juga negara lain. Menggunakan kamera dengan resolusi yang baik dan tidak terdapat banyak noise. Menambah tahap preprocessing data dan memperbanyak metode pengujian.

\section{Daftar Pustaka}

Ahmad, M. B., Park, J.-A., Chang, M. H., Young-Suk, S., \& Choi, T.-S. (2003). Advanced Parallel Processing Technologies (IV ed., Vol. 2834). (G. Goos, J. Hartmanis, \& J. v. Leeuwen, Penyunt.) Berlin, Germany: Springer Berlin Heidelberg. doi:10.1007/978-3-540-39425-9_70

Boodoo-Jahangeer, N. B. (2013, August). Face Recognition Using Chain Code. Journal of Signal and Information Processing, 4, 154-157. doi:10.4236/jsip.2013.43B027

Fatta, H. A. (2007). Konversi Format Citra RGB ke Format Grayscale Menggunakan Visual Basic. Yogyakarta: STMIK AMIKOM Yogyakarta.

Gonzales, R. C., \& Woods, R. E. (2002). Digital Image Processing : Third Edition. Pearson International Edition. Imelda, \& Hartati, S. (2013). Pengenalan Rambu Lalu Lintas Menggunakan Shape Number pada Chain Code. Seminar Nasional Teknologi Informasi dan Komunikasi (SNASTIKOM 2013). Retrieved September 23, 2014, from http://prosiding-snastikomti.stthmedan.ac.id/index.php/doc_download/170-pengenalan-rambulalu-lintasmenggunakan-shape-number-pada-chain-code

Mulyadi, Handry. (2002). Pengenalan Rambu Lalu Lintas Sederhana Dengan Menggunakan Metode Template Matching. Proceedings, Komputer dan Sistem Intelejen (KOMMIT 2002). ISSN 1411-6286

Peraturan Menteri Perhubungan Republik Indonesia Nomor PM 13 Tahun 2014 tentang Rambu Lalu Lintas. Retrieved September 22, 2014, from http://hubdat.dephub.go.id/km/tahun-2014/1626-peraturanmenteriperhubungan-nomor-pm-13-tahun-2014-tentang-rambu-lalulintas/download 